\title{
Vércukor-önellenőrzési adatok intelligens értelmezése
}

\author{
Dió Mihály - Deutsch Tibor dr. - Biczók Tímea - Mészáros Judit dr.
}

Semmelweis Egyetem, Egészségtudományi Kar, Budapest

\begin{abstract}
A vércukor-önellenőrzés a cukorbeteg-gondozás sarokköve. Jelenleg azonban a gondozók és betegek sem aknázzák ki megfelelően az önellenőrzési adatokban rejlő információt. Kevesen töltik le az elektronikus vércukormérókből az adatokat, és még kevesebben vannak azok az orvosok, akik a vizitek alkalmával szisztematikusan elemeznék és értelmeznék a rögzített adatokat. A szerzók bemutatnak egy szisztematikus eljárást, amely alkalmas a 2-4 hónap során gyújtött vércukor- és terápiás adatok elemzésére, értelmezésére, az esetleges beállítási és monitorozási problémák feltárására és okainak felderítésére. Az eljárás során meghatározzák: 1. a glykaemiás kontroll általános minőségét, 2. a hypo- és hyperglykaemiák gyakoriságát, súlyosságát és időbeli előfordulását, 3 . a vércukorértékek variabilitását, 4 . az adatokban megjelenő klinikailag releváns mintázatokat és 5 . az önellenőrzés minőségét. A feltárt jellemzők segítségével elóállítható egy rangsorolt problémalista, ami segítheti az egyes problémák okainak feltárását. Ezek alapján elvégezhetők azok a módosítások a beteg kezelésében és életmódjában, amelyek várhatóan megszüntetik a kimutatott problémákat. Orv. Hetil., 2015, 156(29), 1165-1173.
\end{abstract}

Kulcsszavak: klinikai döntéstámogatás, diabetes mellitus, önellenőrzés, orvosinformatika

\section{Intelligent interpretation of home monitoring blood glucose data}

Self monitoring of blood glucose is the cornerstone of diabetes management. However, the data obtained by self monitoring of blood glucose have rarely been used with the highest advantage. Few physicians routinely download data from memory-equipped glucose meters and analyse these data systematically at the time of patient visits. There is a need for improved methods for the display and analysis of blood glucose data along with a modular approach for identification of clinical problems. The authors present a systematic methodology for the analysis and interpretation of self monitoring blood glucose data in order to assist the management of patients with diabetes. This approach utilizes the followings 1 ) overall quality of glycemic control; 2) severity and timing of hypoglycemia and hyperglycemia; 3 ) variability of blood glucose readings; 4) various temporal patterns extracted from recorded data and 5) adequacy of self monitoring blood glucose data. Based on reliable measures of the quality of glycaemic control and glucose variability, a prioritized problem list is derived along with the probable causes of the detected problems. Finally, problems and their interpretation are used to guide clinicians to choose therepeutic actions and/or recommend behaviour change in order to solve the problems that have been identified.

Keywords: clinical decision support, diabetes mellitus, medical informatics, self-monitoring

Dió, M., Deutsch, T., Biczók, T., Mészáros, J. [Intelligent interpretation of home monitoring blood glucose data]. Orv. Hetil., 2015, 156(29), 1165-1173.

(Beérkezett: 2015. április 24.; elfogadva: 2015. május 21.)

\section{Rövidítések}

$\mathrm{ADRR}=$ átlagos napi kockázati tartomány; $\mathrm{HbA}_{\mathrm{lc}}=$ glikohemoglobin; $\mathrm{IQR}$ = interkvartilis tartomány; $\mathrm{LI}=$ labilitási index; MAGE = glykaemiás ingadozások amplitúdójának átlaga; SD = szórás; SMBG = vércukor-önellenőrzés
Különböző multicentrikus vizsgálatok egyértelműen igazolták, hogy a diabetes súlyos késői szövődményei megfelelő beállítással jelentősen késleltethetők és sok esetben elkerülhetők [1]. A gondozás során ezért a betegek vércukorszintjét egy meghatározott céltartomány- 
ban szükséges tartani [2]. A beállításnál figyelembe kell venni azt is, hogy a glükózszint változékonyságából eredő oxidatív stressz szintén hozzájárul a macro- és microvascularis szövődmények kialakulásához [3].

A memóriával ellátott vércukorméróket több mint 20 éve használják, ezek nagy részéhez olyan program is kapcsolódik, amely lehetôvé teszi a gyưjtött adatok tárolását, letöltését és elemzését. Számos kitúnő összefoglaló jelent meg a jelenleg használatos vércukormérő eszközökról és a hozzájuk kapcsolódó adatelemzési és adatmegjelenítési szolgáltatásokról [4, 5]. A vércukormérésen túlmenően számos funkciót építettek be a különböző készülékekbe. Ezek közül különösen fontos, hogy a betegek a mért adatokhoz különböző megjegyzéseket is csatolhatnak. Bejelölhetik például, hogy egy kiugróan magas vércukorérték egy szokatlanul szénhidrátdús étkezés következménye, amit az elemzés során természetesen figyelembe kell venni.

Sok készülék végez különböző bonyolultságú statisztikai elemzéseket és készít olyan ábrákat, amelyek jól mutatják a vércukortrendeket. Az ilyen ábrákon gyakran nem csupán a vércukorértékek, hanem egyéb befolyásoló tényezők - például inzulin, extra szénhidrátbevitel - is megjeleníthetók. Gyakran azt is be lehet állítani, hogy mely napokon (például csak hétvége) és napszakokban (például csak reggeli és vacsora előtt) mért vércukorértékeket és injiciált inzulinadagokat akarjuk áttekinteni.

A jelenleg használatos vércukormérők zöme képes a tárolt adatokat letölteni egy számítógépbe USB-kábelen vagy infravörös kapcsolaton keresztül. Ilyenkor a rögzített adatokat a vércukormérőhöz tartozó adatmenedzselő szoftver segítségével lehet elemezni [6]. Ez különösen fontos az orvos-beteg találkozások alkalmával, amikor az orvosnak egy hosszabb (4-8 hét) időszak alatt regisztrált önellenőrzési adatokat kell feldolgozni, és ezekből kell megállapítani, hogy a beteg jól van-e beállítva, és ha nem, miként kell módosítani a korábbi kezelését.

A gyakorlatban, sajnos, több tényező gátolja a vércukor-önellenőrzési (SMBG-) adatokban rejlő információ teljes kiaknázását. Több orvos tévesen úgy gondolja, hogy nincs szükség az SMBG-adatok részletes elemzésére, hiszen a $\mathrm{HbA}_{\mathrm{lc}}$-értékek önmagukban is megfelelö képet adnak a beállítás minőségéről. Kevés orvos tölti le rutinszerüen a betegek adatait, és még kevesebben vannak olyanok, akik szisztematikusan elemzik és értelmezik is a letöltött adatokat. A rendelkezésre álló szúkre szabott idő gyakran valóban nem elegendő ahhoz, hogy a gondozóteam alaposan áttekintse a vizitek közti időben rögzített adatokat, feltárja a különböző beállítási problémákat és ezek alapján megfelelő döntéseket hozzon.

A vércukor önellenőrzése ugyanakkor öncélúvá válik, ha nem tudjuk kinyerni az adatokban rejlö valamennyi fontos információt és ezt nem csatoljuk vissza a gondozási folyamatba. Ehhez a jelenleg elérhető informatikai megoldások, sajnos, nem adnak elégséges fogódzót [7]. $\mathrm{Az}$ önellenőrzési adatok vizualizációja és statisztikai feldolgozása természetesen nagyon fontos eszközök, de a klinikailag releváns információ megbízható kinyeréséhez egy jól átgondolt intelligens adatértékelő és -elemző informatikai rendszerre van szükség. Ebben a közleményben egy ilyen rendszer körvonalait igyekszünk felvázolni.

\section{Az SMBG-adatok szisztematikus feldolgozása}

A hagyományos orvos-beteg találkozások legfontosabb végtermékei azok az ajánlások, amelyek megszabják a páciensek diétáját, gyógyszeres vagy inzulinterápiáját, és azt is, hogy mikor és milyen sürüséggel mérjék meg a vércukor szintjét az elkövetkező időszakban. A javasolt diétás, terápiás és monitorozási tervet alapvetóen a vizit alkalmával feltárt életmódbeli, beállítási és complianceproblémák jelölik ki. Az önellenőrzési adatok intelligens értelmezése így végső soron a problémafelismerés és diagnózis eszköze [8]. A problémák feltárásáig a gondozási napló adatainak megjelenítésén, statisztikai elemzésén (összegzésén) és a különböző problémákra utaló motívumok/mintázatok kinyerésén keresztül vezet az út.

Az intelligens adatelemzés szerepét a krónikus gondozási folyamatban az 1 ábra mutatja be. A betegek által rögzített adatok jelentik az intelligens adatelemzés nyersanyagát. Ezekkel az egyedi bejegyzésekkel azonban nem sokra megyünk, ha nem tudjuk összegezni, hogy mi történt a megelőző vizit óta eltelt időben és nem győződünk meg arról, hogy ez a vércukortörténet összhangban van az előzetes várakozásainkkal. Például, ha a megelőző vizit óta jelentősen emeltük a páciens napi inzulinadagját, meglepő lenne, ha az önellenőrzési adatok szerint tovább emelkedtek volna a vércukorértékek. Inkonzisztencia esetén az adatokat újra kell elemezni.

Ha az önellenőrzési adatokból egy konzisztens történet rajzolódik ki, továbbléphetünk az adatok intelligens értelmezéséhez, más szóval a problémák feltárásához. Az adatok intelligens értelmezése túlmegy a szokásos leíró statisztikai elemzéseken, amelyek teljesen figyelmen kívül hagyják a különböző időpontokban mért vércukorértékek, továbbá kezelési és életmódbeli adatok kapcsolatát. Nyilvánvaló például, hogy az egymást követő vércukormérések nem függetlenek egymástól. Egy ebéd előtt mért 9,5 mmol/l vércukorérték jelentése attól függ, hogy alacsony, normális vagy éppen igen magas vércukorértéket mértünk a reggeli étkezést megelőzően. Ezért óvatosan kell bánnunk a különböző leíró jellemzőkkel, és bonyolultabb módszereket kell használnunk az adatokban rejlő klinikai információ kinyeréséhez.

A klinikailag releváns információt különböző mintázatok hordozzák $[9,10,11]$. Egy időszakon keresztül érvényesülő mintázat sokkal informatívabb, mint az egyes mérési adatok vagy izolált mérések halmaza. Az adatok intelligens értelmezése során azt vizsgáljuk, hogy az önellenőrzési adatokban mikor, milyen gyakorisággal és milyen mintázatok fordulnak elő. A különböző mintázatok kinyerésére olyan érvelő és mintaillesztési módszereket 


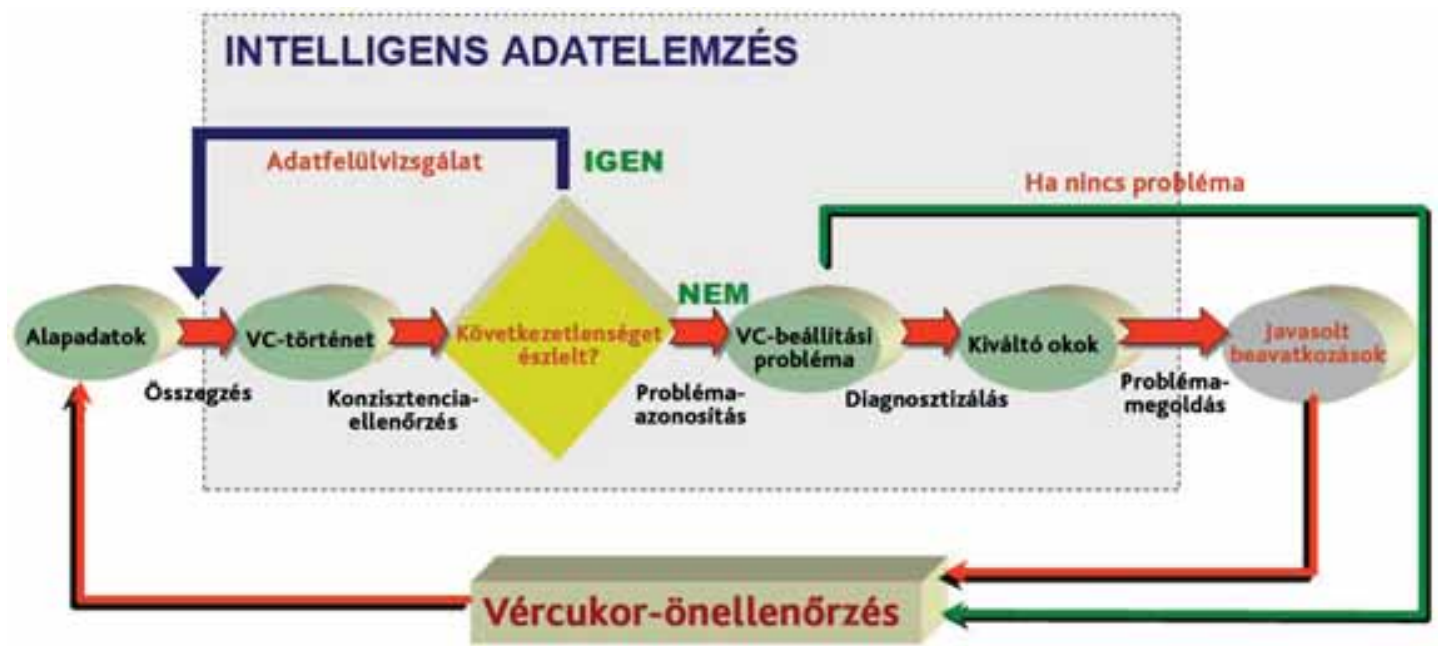

1. ábra $\mid \begin{aligned} & \text { Az intelligens adatelemzés szerepe a gondozási folyamatban } \\ & \mathrm{VC}=\text { vércukor }\end{aligned}$

1. táblázat | Vércukorértékek napi bontásban (A 77 Elektronika Kft. engedélyével)

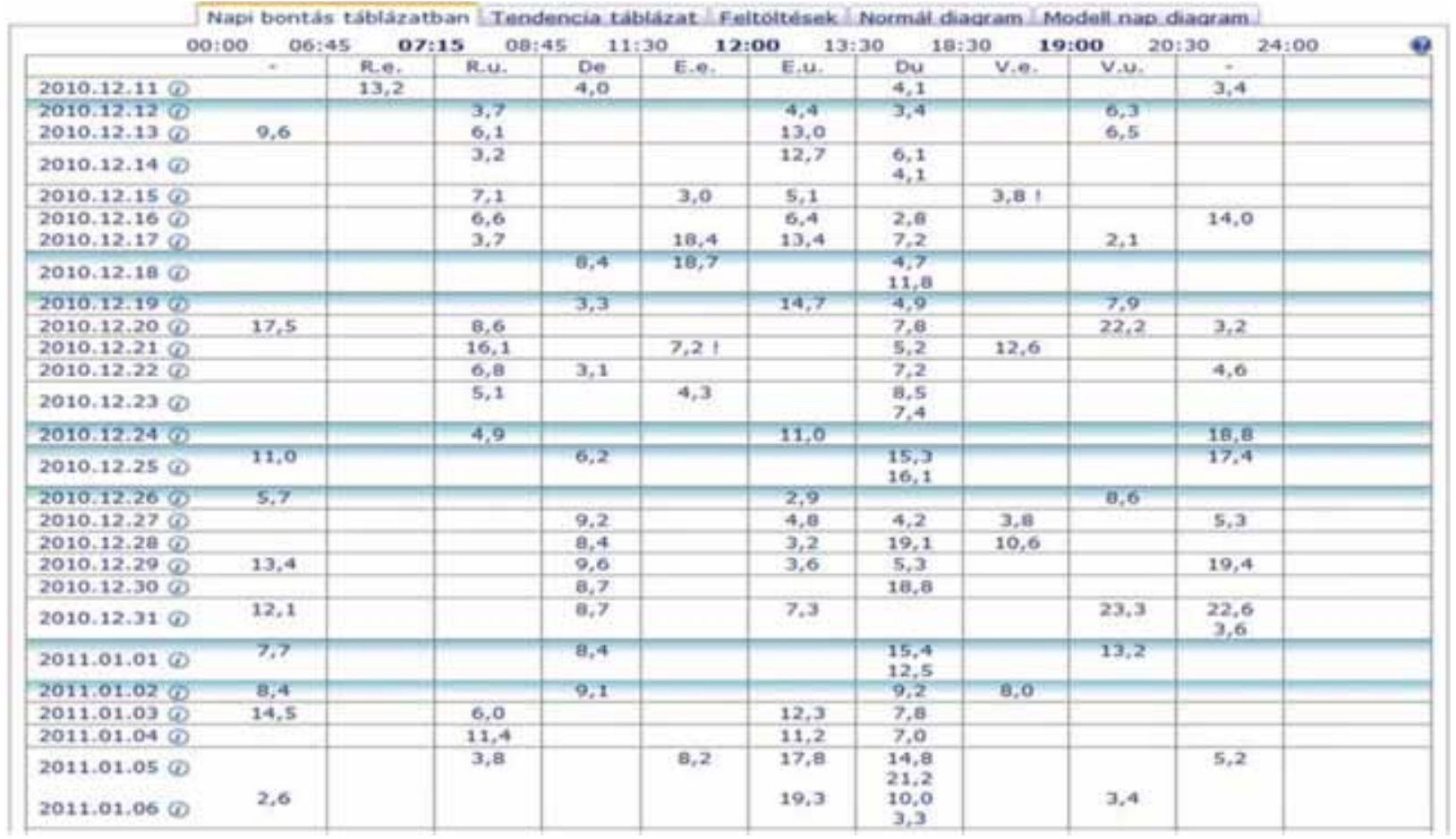

használunk, amelyeket a tapasztalt diabetológusok intuitív módon alkalmaznak.

A folyamat utolsó fázisában természetesen választ kell adnunk arra a kérdésre is, hogy mi okozta a jelentkező problémákat.

\section{SMBG-adatok időbeli áttekintése}

$\mathrm{Az}$ önellenőrzési adatokkal történő első ismerkedést szolgálja a vércukorértékek táblázatos megjelenítése (1. táblázat).
Az önellenőrzési adatok grafikus bemutatása megkönnyíti a vércukorszintek áttekintését. A 2. ábrán például az egymást követő napokon regisztrált vércukoradatok láthatók.

\section{SMBG-adatok elemzése}

A betegek által rögzített vércukoradatokat az alábbi szempontok szerint kell elemezni [12]:

1. szempont: Vércukor-beállítás általános minősége. (Mennyire jó a beállítás a célokhoz képest?) 
Mérések száma: 94

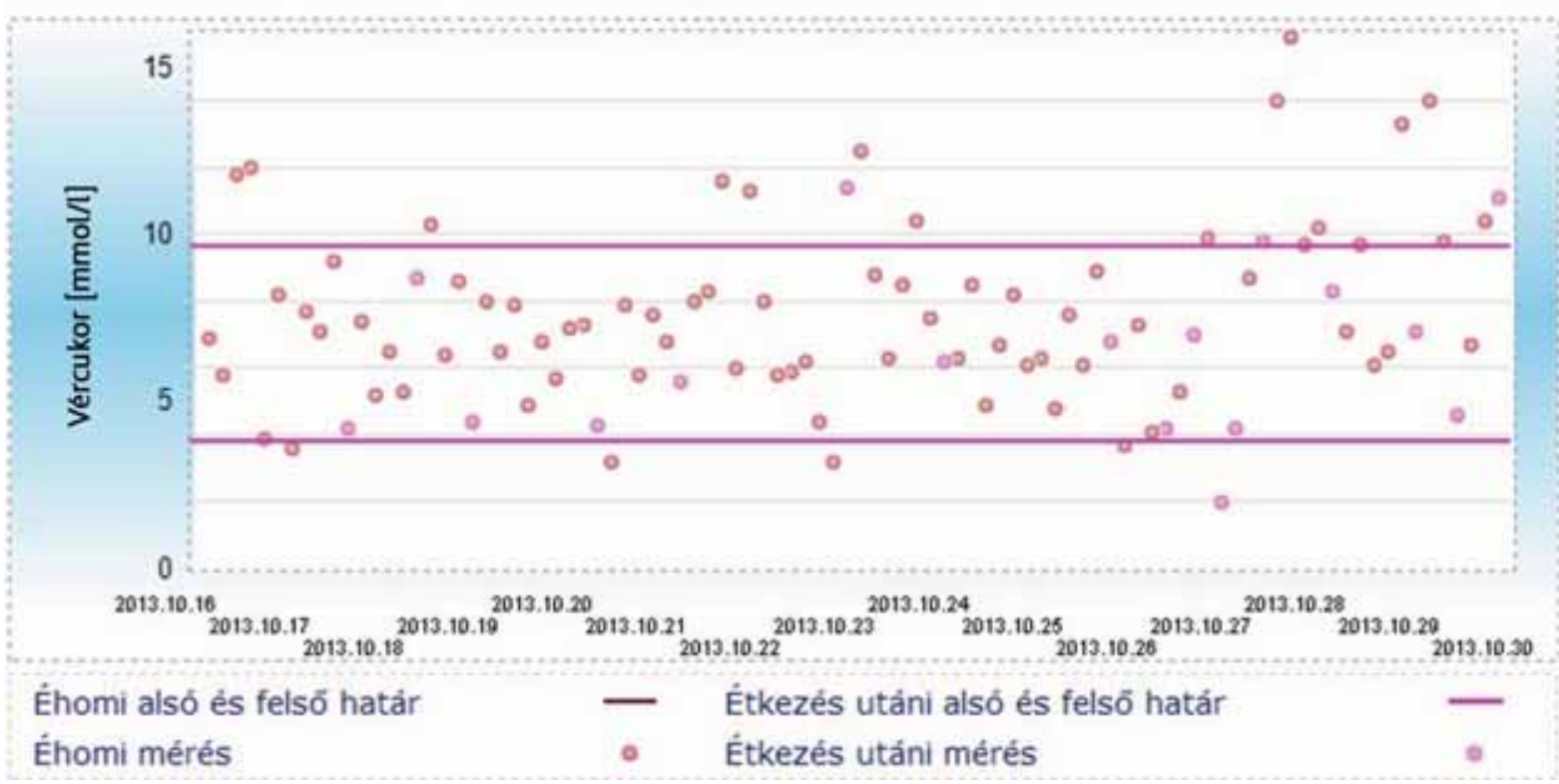

2. ábra

| Napi vércukorértékek (A 77 Elektronika Kft. engedélyével)

- Vércukorértékek átlaga és medián értéke. (Mivel a vércukorértékek általában nem normáleloszlásúak, célszerü a mediánt használni.)

- A mért vércukorszintek hány százaléka kisebb a különböző időpontokhoz kijelölt céltartományok alsó határánál, hány százaléka esik a kijelölt tartományba, illetve haladja meg a céltartomány felső határát?

- Átlagos prae- és postprandialis vércukorértékek napszakonként, étkezésenként és összesítve.

2. szempont: Vércukorértékek variabilitása.
- Vércukorértékek szórása, variációs együtthatója, legalacsonyabb és legmagasabb érték, tartomány. (A szórás és tartomány érzékeny a kiugró értékekre.)

- Percentilisek és interkvartilis tartomány. (Célszerú az IQR-értéket használni, amelynek segítségével megbecsülhetjük a szórás értékét is: SD' = IQR/1,35 [12].)

- A különböző tartományokba eső vércukorértékek gyakorisága a különböző napszakokban.

- Kombinált indexek (LI, M-érték, MAGE, J-index, ADRR) $[13,14,15]$. Az ADRR értéke azt mutatja,

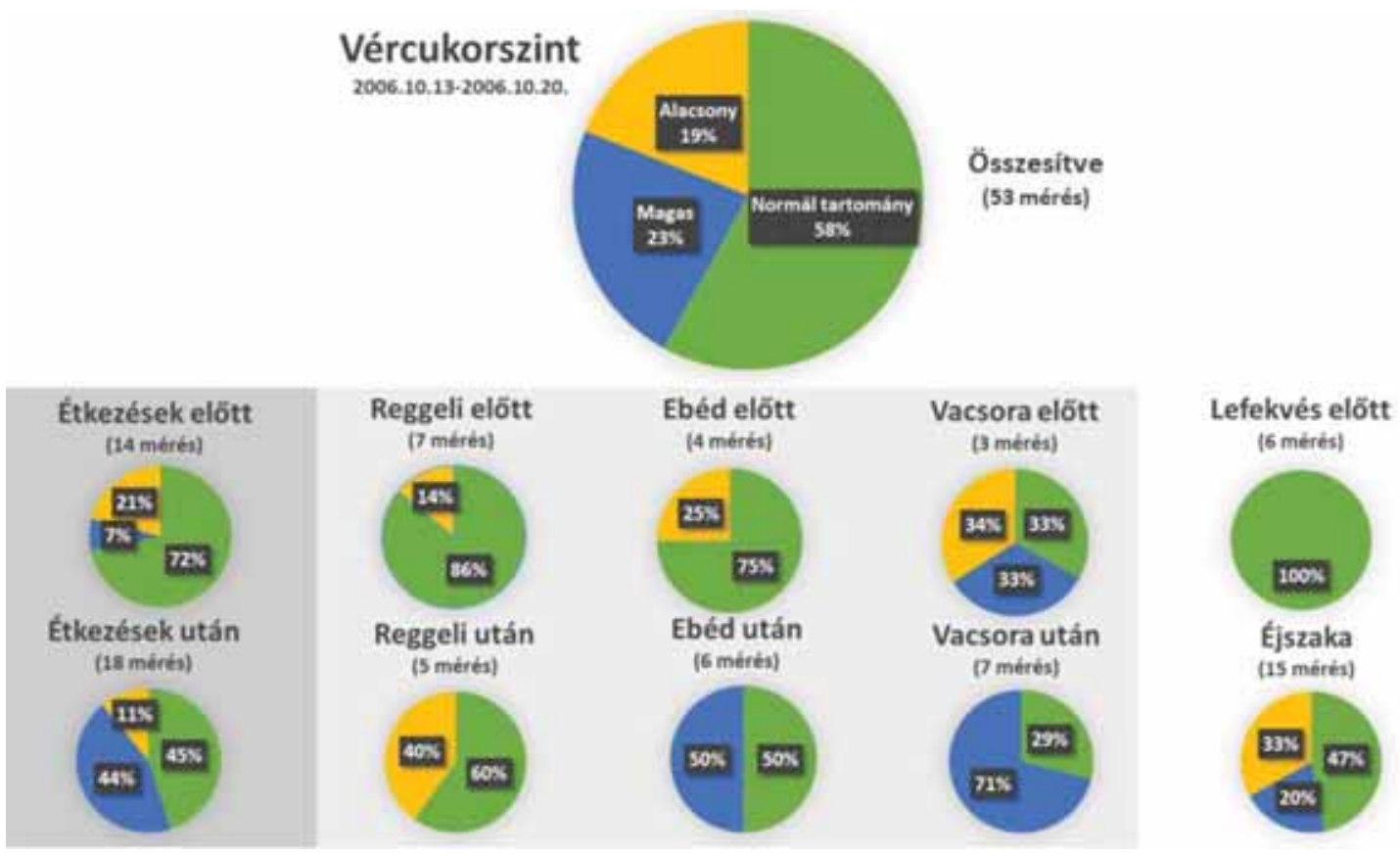

3. ábra | Különböző vércukorértékek gyakorisága időszakonként 
2. táblázat | Vércukorértékek leíró statisztikái a különböző napszakokban (A 77 Elektronika Kft. engedélyével)

Napi bontás táblázatban Tendencia táblázat Feltöltések Normál diagram Modell nap diagram

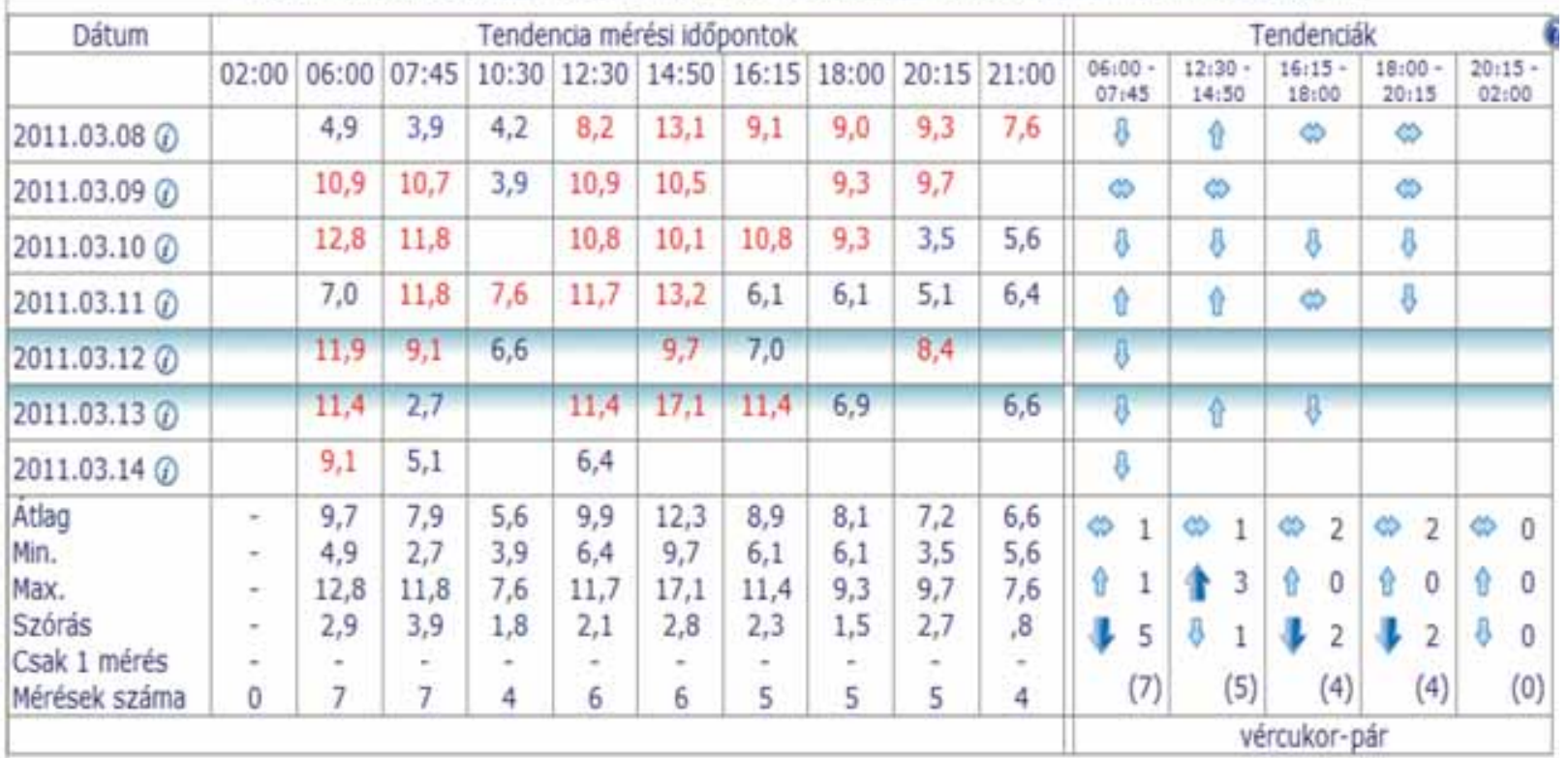

hogy a vércukorértékek milyen gyakran vannak a megadott tartományon kívül (például $4 \mathrm{mmol} / \mathrm{l}$ alatt vagy $10 \mathrm{mmol} / \mathrm{l}$ felett).

A 3. ábrán a különböző tartományokba eső vércukorértékek gyakoriságát szemléltetjük. A 2. táblázatban a különböző időpontokban mért vércukorértékek leíró statisztikái láthatók. Az SMBG-adatok elemzésének egyik legfontosabb célja a napi vércukorprofil megszerkesztése. A 4. ábrán egy ilyen profilt mutatunk be doboz-pálcika diagram (Box plot) formájában. Látható, hogy az egyes napszakokban a mérési adatok erôsen szóródnak, ezért a kiszámított napi tipikus profil nem nyújt megbízható támpontot az inzulinadagok módosításához.

3. szempont: Hypo- és hyperglykaemiák alakulása.

- Hypoglykaemiák/hyperglykaemiák összes száma.

- Hypoglykaemiák/hyperglykaemiák száma az egyes napszakokban (délelőtt, délután, este, éjszaka).
- Hypoglykaemiák/hyperglykaemiák súlyossága.

4. szempont: Mintázatok az adatokban. Az alábbi listában néhány fontosabb mintázatot sorolunk fel:

- Napszaki túlzott vércukor-emelkedés. (Két egymást követő praeprandialis vércukorérték különbsége meghalad egy kritikus értéket - például $3 \mathrm{mmol} / \mathrm{l}$.)

- Somogyi-effektus (hypoglykaemiát követő magas vércukorértékek).

- Metabolikus instabilitás (erős ingadozás és kiszámíthatatlanság a vércukorértékekben).

- Hajnali jelenség. (Reggeli előtt mért vércukorérték meghalad egy kritikus szintet, például $12 \mathrm{mmol} / 1$, és a megelőző napon lefekvéskor mért vércukorérték a normáltartományba esik, éjszaka pedig nem volt hypoglykaemia vagy mért alacsony vércukorérték.)

- Kiegyensúlyozatlan napi vércukorprofil. (A legnagyobb és legkisebb napi praeprandialis vércukorérték közti eltérés meghaladja a 3,5 mmol/1 értéket.)

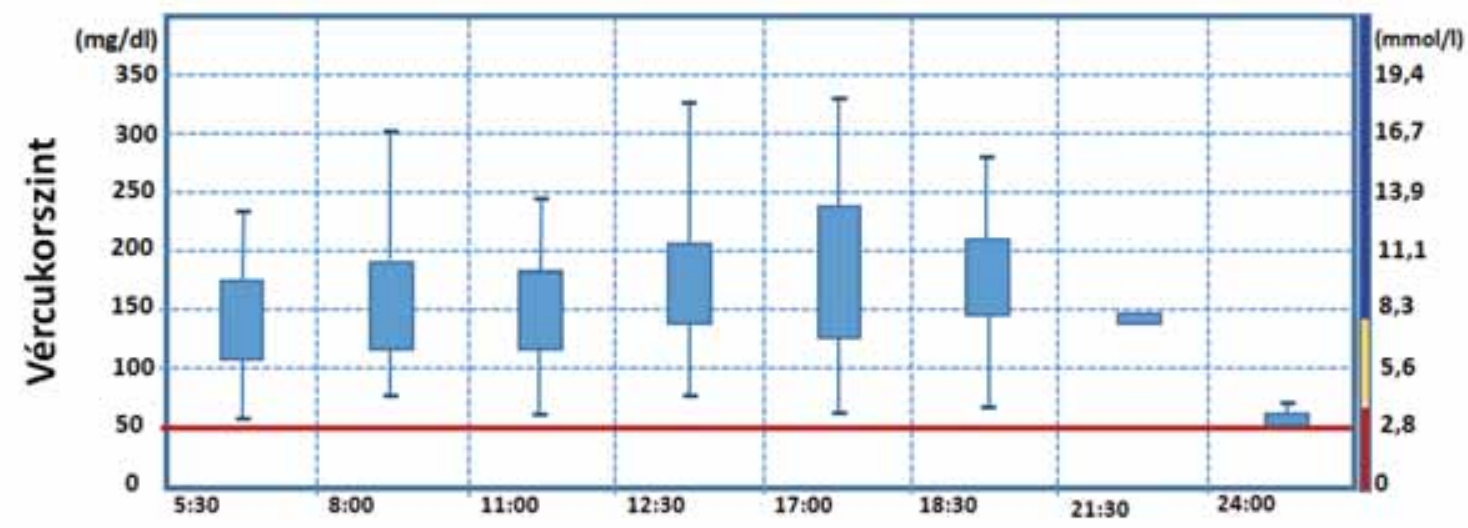

4. ábra $\quad$ A napi vércukorprofil ábrázolása Box plot segítségével 


\section{Időbeli absztrakciók}

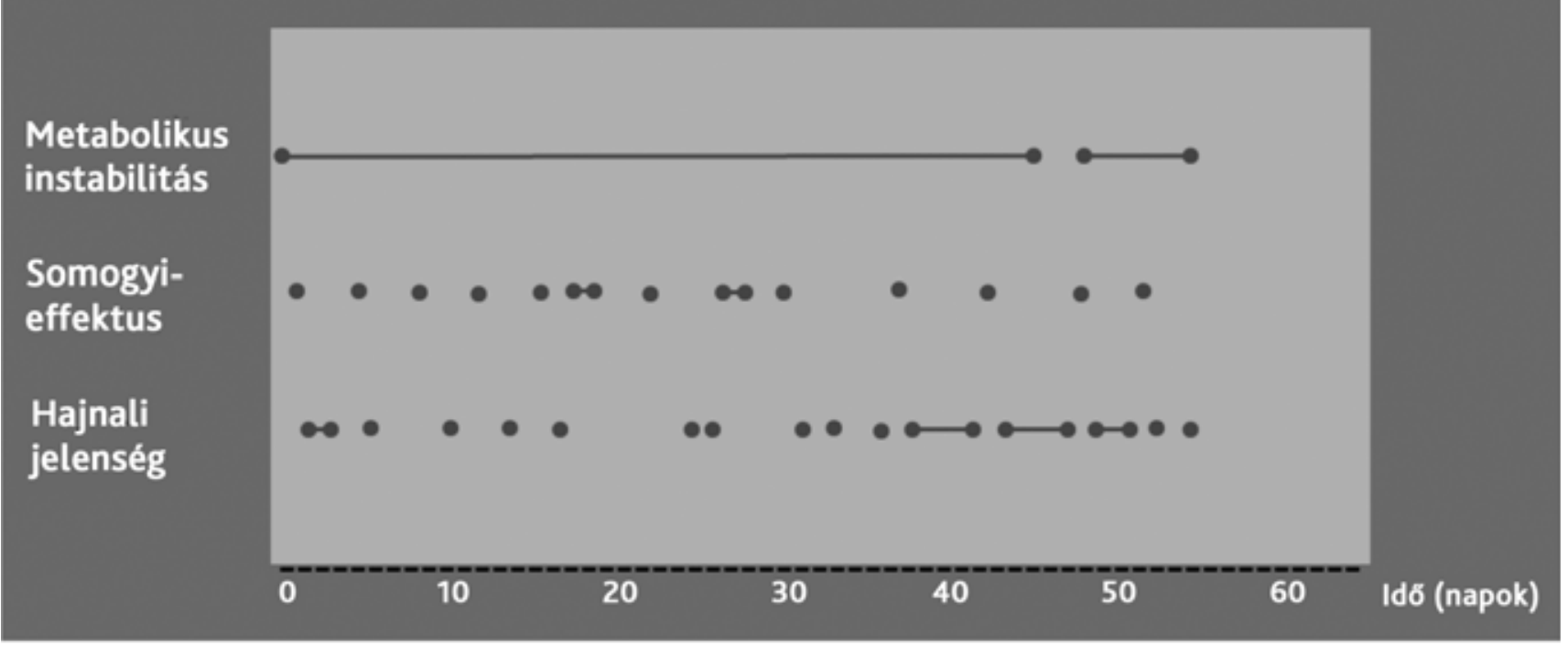

5. ábra

| Vércukortörténet feltárt mintázatok alapján

Az 5. ábrán a vércukortörténetet a feltárt absztrakt időbeli mintázatok nyelvén meséljük el, ami sokkal informatívabb a klinikus számára, mint az egyedi vércukoradatok időbeli alakulásának az ábrázolása.

5. szempont: Monitorozás minősége.

- Vércukormérések összes száma.

- Mérések száma az egyes időpontokban.

- Mérési párok száma az egyes napszakokban.

- Teljes vércukorprofilok száma.

- Az előírásokhoz képes miként végzi az önellenőrzést. (Az egy hét alatt beérkező mérések száma kisebb, megegyezik vagy nagyobb, mint az előírt mérésszám.)

\section{Konzisztenciavizsgálatok}

Az előzőekben bemutatott módszerek segítségével képet kaphatunk arról, hogy miként alakultak a beteg vércukorértékei a megelőző vizit óta eltelt időszakban. A kialakított képre azonban csak akkor támaszkodhatunk feltétel nélkül a továbbiakban, ha az összhangban van a gondozás során mért egyéb adatokkal és nem utolsósorban elözetes várakozásainkkal. Például:

- Az utóbbi két hónapban mért vércukoradatok összhangban vannak-e a laboratóriumban meghatározott $\mathrm{HbA}_{\mathrm{lc}}$-értékkel?

- A vércukoradatok jellemzői összhangban vannak-e az életmódban, illetve az alkalmazott kezelésben történt módosítássokkal?

A 6. ábrán azt szemléltetjük, hogy az inzulinadagok módosítása milyen hatást gyakorolt a vércukorértékek eloszlására. A különböző időpontokban történt inzulindózis-emelések hatásai jól tükröződnek az A, B és C vércukorhisztogramok alakjában és az átlagos vércukorértékek csökkenésében egyaránt. A vércukorszintekben olyan változások történtek, amelyeket a módosított gyors hatású és NPH inzulinkészítmények farmakodinámiás hatása alapján vártunk.

\section{Problémák feltárása}

Az önellenőrzési adatok elemzésének végső célja a különböző beállítási és compliance-problémák feltárása. A problémákra az előző pontban felsorolt elemzések (beállítás minősége, hypoglykaemia, hyperglykaemia, variabilitás, mintázatok és monitorozás minősége) eredményeiből következtethetünk. Az alábbiakban néhány probléma definícióját soroljuk fel:

- Éjszakai hypoglykaemia (már egy is elég).

- Gyakori hypoglykaemia. (Az éjszaka kivételével bármely napszakban a hypoglykaemiás epizódok száma+a mért hypoglykaemiás vércukorértékek száma egy hét alatt meghalad egy kritikus értéket, például 3.)

- Hyperglykaemiás állapot. (A vizsgált időszakban legalább M [például 10] vércukormérés történt és minden jellemző időpontban [fóétkezések és lefekvés előtt] történt legalább 2 mérés, és a vércukorértékeknek több mint egy adott százaléka [például 80\%] meghaladja a megadott felső határértéket, és nem volt egyetlen hypoglykaemia sem.)

- Praeprandialis hyperglykaemia egy adott idópontban. (Az adott időpontban [reggeli, ebéd, vacsora, illetve lefekvés előtt] legalább $M$ [például 6] vércukormérés történt, és a mért vércukorértékeknek több mint egy adott százaléka [például 80\%] meghaladja a megadott felső határértéket, és az adott időpontot megelőző 12 órában nem volt hypoglykaemia.)

- Nagy vércukor-variabilitás. (Egy héten egy adott számnál [például 2] több hypoglykaemia fordul elő, és 


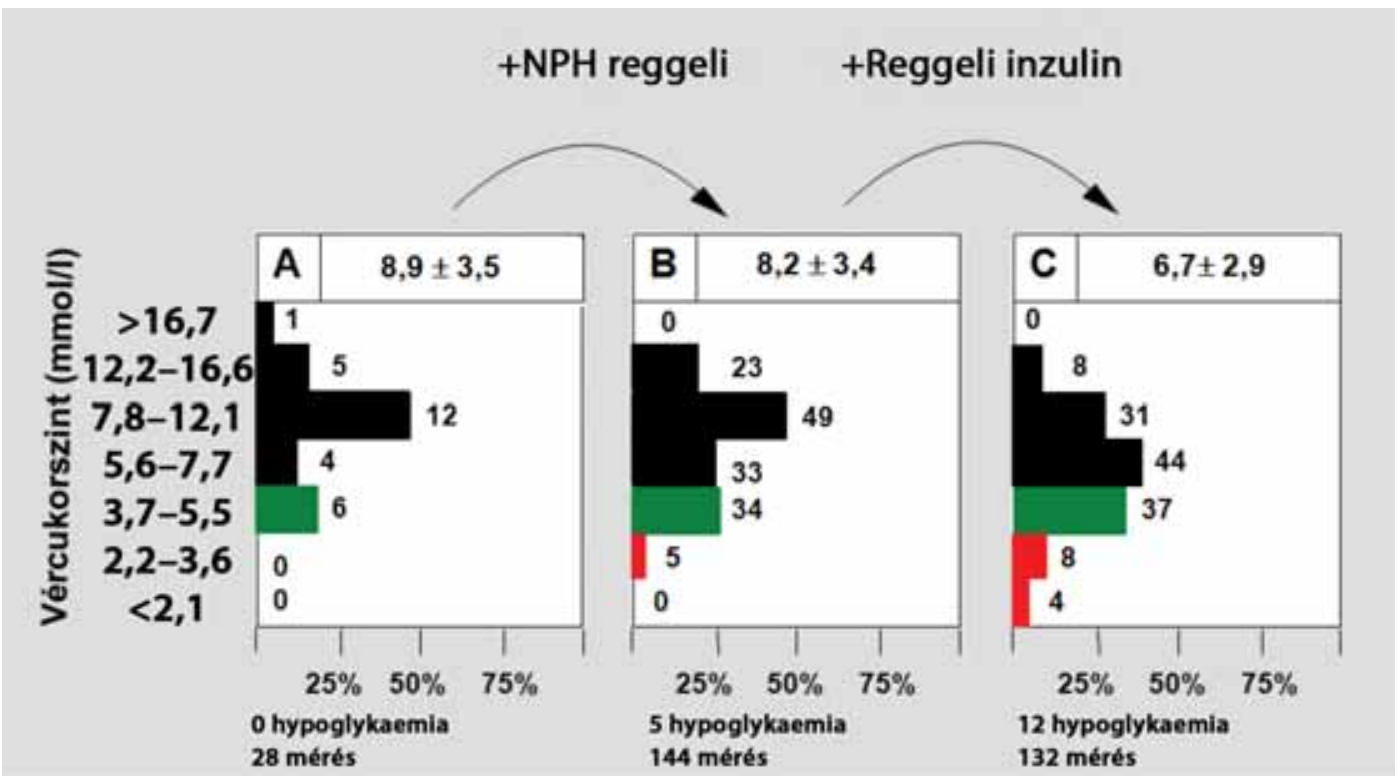

6. ábra

| Inzulinadagok módosításának hatása a vércukorértékek eloszlására

a vércukorértékek több mint egy adott százaléka [például 60\%] hyperglykaemiás, vagy a vércukorértékek szórása >0,33×vércukorátlag vagy $\mathrm{ADRR}>40$ ) [12].

- Elégtelen monitorozás: az elvégzett mérések száma több mint 50\%-kal elmarad a javasolt monitorozási gyakoriságtól. (Egyes, páros mérésekre, valamint teljes napi profilokra egyaránt meg kell vizsgálni és jelezni a problémát.)

- Erősen emelkedő vércukortrend.

A problémákat rangsorolni kell. A prioritások természetesen klinikusonként változhatnak, és nyilvánvalóan függnek a beteg állapotának természetétől (diabetes típusa, tartama, terápia típusa, társbetegségek, aktuális szövődmények stb.).

\section{Problémadiagnosztika}

A feltárt problémákat csak akkor tudjuk célzottan megszüntetni, ha ismerjük az előidéző okokat is. Amennyiben például a délelőtt folyamán a vércukorszintek rendszeresen jelentősen emelkednek, feltehetően elégtelen a reggel adott inzulin hatása és ezért változtatni kell a beteg kezelésén. A problémák okának feltárásához kapcsolatot kell keresnünk a feltárt mintázatok, valamint a páciens életmódja, együttmúködési készsége, diétája és terápiája között.

Ebben segíthet, ha a praeprandialis és lefekvéskor regisztált vércukorértékek gyakorisági eloszlását azokkal az inzulinadagokkal társítjuk, amelyek az adott időszakban maximális hatást fejtenek ki. A 7. ábrán jól látszik a keze-

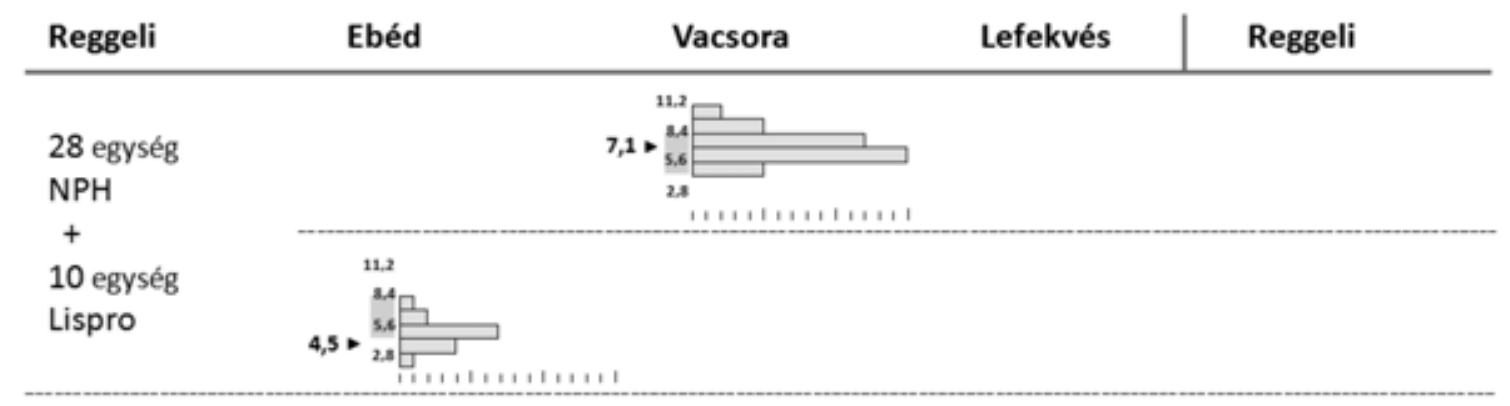

12 egység
Lispro




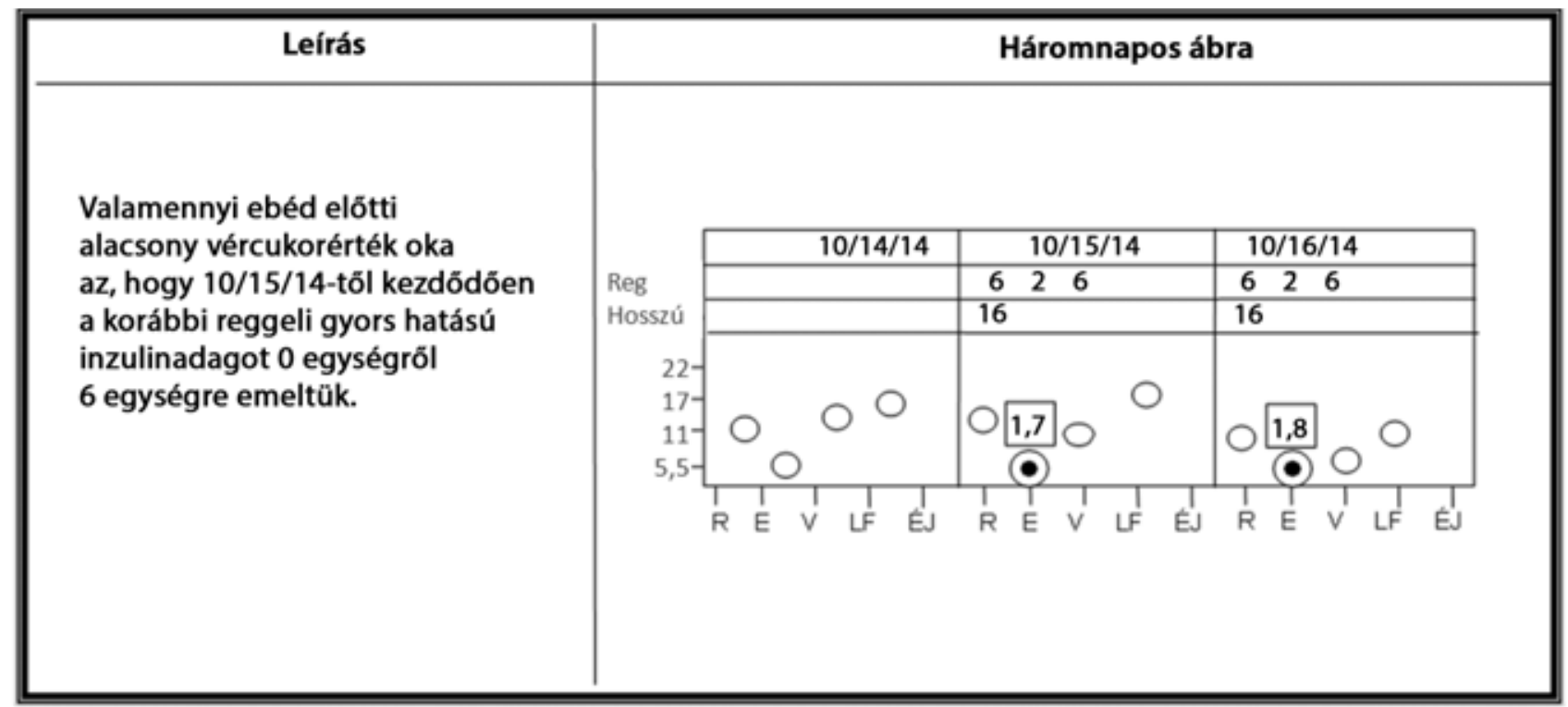

8. ábra

| Gondozási napló adatai a kérdéses időszak környezetére fokuszálva

lés hatása a vércukorértékekre, és az is, hogy a beteg mennyire követte a monitorozási elóírásokat [16]. A beállítási problémák okának megállapítása gyakran nem egyszerü. Egyes esetekben több magyarázat is szóba jöhet, amelyekből egymással ellentétes irányú terápiamódosítások adódnak. Például, ha az éhomi hyperglykaemiát a hajnali jelenség okozza, a lefekvéskor adott inzulin adagját növelni kell. Nem feledkezhetünk meg azonban arról a lehetőségról sem, hogy a reggeli hyperglykaemia hátterében egy előző napi hypoglykaemia által kiváltott Somogyi-effektus áll.

A tényleges okok feltárásához jó szolgálatot tesz, ha a gondozási napló adatait a kérdéses időszak környezetére fokuszálva mutatjuk be ( 8 . ábra).

Az egyes napszakokra vonatkozó kép kialakításánál figyelembe kell venni a beteg együttmúködési készségét és azt is, hogy megfelelően alkalmazza-e az intenzifikálás technikáit. Hiszen például a gyakori hypoglykaemiák oka az is lehet, hogy a beteg sokszor végez megterhelő fizikai munkát, amelyet nem rögzít a kezelési naplóban, vagy nem csökkenti ennek megfelelően az inzulinadagját.

\section{Következtetések}

A glükométerekben tárolt SMBG-adatok letöltése, megjelenítése és elemzése jelentősen segítheti a cukorbetegek menedzselését $[17,18]$. Ennek ellenére ezt a megközelítést korántsem alkalmazzák széleskörüen.

$\mathrm{Az}$ adatok letöltésének számos akadálya van, amelyekkel foglalkozni kell. A munkafolyamatba illesztés és a finanszírozás egyaránt gondot okoz, de a jelenlegi glükométerek és a hozzájuk kapcsolódó szoftverek által közölt riportok rugalmasságát és minőségét egyaránt javítani kell. Az idegenkedés egyik oka ugyanis az, hogy az elemzőprogramok nem nyújtanak teljes körü és felhasználó- barát szolgáltatást. Az önellenőrzési adatok jelenleg alkalmazott vizualizációja és statisztikai feldolgozása korántsem elegendő a vércukor-beállítási problémák intelligens elemzéséhez [19].

Közleményünkben egy olyan szisztematikus eljárást mutattunk be, amely segíti a klinikusokat a vércukoradatok elemzésében, a potenciális beállítási problémák feltárásában és diagnosztizálásában. A módszer kialakításánál az orvos-beteg találkozások követelményeit tartottuk szem előtt. A gondozó orvosnak egy hosszabb (4-8 hét) időszak alatt regisztrált önellenőrzési adatokat kell feldolgoznia, ezekből kell megállapítania, hogy a beteg jól van-e beállítva, és ha valamilyen problémát észlel, a beteg életmódját és/vagy terápiáját kell módosítania. A bemutatott módszer segítségével az SMBG-adatok feldolgozásának eredményét a terápia módosítására fordíhatjuk le.

A leírt komplex statisztikai mintaillesztést és érvelést a háttérben kell elvégezni, és csak a klinikailag releváns információt kell közölni az orvossal a kívánt formában. A különböző ábrák és táblázatok megjelenítésénél arra az üzenetre kell fokuszálni, amelyet közölni szeretnénk, vagy amit a felhasználó klinikus látni szeretne. Lehetővé kell tenni, hogy az orvosok különböző szempontok szerint tekinthessék meg az adatokat, és az időhorizont, valamint az aktuális probléma függvényében különböző kérdéseket tehessenek fel [20].

A bemutatott módszerek segítségével a viziteket megelőzően ki lehet értékelni a gondozási napló több hónapos adatait. A nagy tömegú adat feldolgozása különösen lényeges, ha figyelembe vesszük, hogy a közeli jövőben a rutinellátásba tömegesen bekerülnek majd a különböző noninvazív vércukormérő eszközök, és az ezekből származó adattömeget a jelenlegi módszerekkel már lehetetlen lesz feldolgozni. 
Anyagi támogatás: A közlemény megírása, illetve a kapcsolódó kutatómunka anyagi támogatásban nem részesült.

Szerzői munkamegosztás: D. M.: A kézirat megszövegezése. D. T.: Elemzések. B. T.: Ábrák szerkesztése. M. J.: Tanácsadó. A cikk végleges változatát valamennyi szerzó elolvasta és jóváhagyta.

Érdekeltségek: A szerzőknek nincsenek érdekeltségeik.

A kézirat Dió Mihály PhD-kutatásához kapcsolódik, amelynek témavezetője dr. Deutsch Tibor.

\section{Irodalom}

[1] The absence of a glycemic threshold for the development of long-term complications: the perspective of the Diabetes Control and Complications Trial. Diabetes, 1996, 45(10), 12891298.

[2] Benjamin, E. M.: Self-monitoring of blood glucose: the basics. Clin. Diab., 2002, 20(1), 45-47.

[3] Hirsch, I. B.: Glycemic variability: it's not just about Alc anymore! Diabetes Technol. Ther., 2005, 7(5), 780-783.

[4] Ajai, O., Tiwari, A., Alcock, J. R.: Evaluation of the state-of-theart in informatics in glucometers. Inform. Health Soc. Care, $2009,34(3), 171-179$.

[5] Mendosa, D.: The diabetes monitor (2010). Blood glucose meters. www.diabetesmonitor.com/meters.htm

[6] Blanchet, K. D.: Telehealth and diabetes monitoring. Telemed. J. E-Health, 2008, 14(8), 744-746.

[7] Blonde, L., Karter, A. J.: Current evidence regarding the value of self-monitored blood glucose testing. Am. J. Med., 2005, 118(Suppl. 9A), 20S-26S.

[8] Deutsch, T., Gergely, T., Lévay, Á: A new care model and intelligent infocommunication system in chronic disease management, Part I. [Új ellátási modell és intelligens infokommunikációs rendszer a krónikus beteggondozásban, I. rész.] IME, 2009 $8(8), 32-36$. [Hungarian]

[9] Bellazzi, R. Larizza, C. Magni, P., et al.: Intelligent analysis of clinical time series: an application in the diabetes mellitus domain. Artif. Intell. Med., 2000, 20(1), 37-57.
[10] Shahar, Y., Cheng, C.: Intelligent visualisation and exploration of time-oriented clinical data. Top. Health Inf. Manage., 1999, 20(2), 15-31.

[11] Deutsch, T., Gergely, T., Trunov, V.: A computer system for interpreting blood glucose data. Comput. Methods Programs Biomed., 2004, 76(1), 41-51.

[12] Rodbard, D.: Optimizing display, analysis, interpretation and utility of self-monitoring of blood glucose (SMBG) data for management of patients with diabetes. J. Diabetes Sci. Technol., 2007, $1(1), 62-71$.

[13] Kovatchev, B. P., Cox, D. J., Gonder-Frederick, L., et al.: Methods for quantifying self-monitoring blood glucose profiles exemplified by an examination of blood glucose patterns in patients with type 1 and type 2 diabetes. Diabetes Technol. Ther., 2002, 4(3), 295-303.

[14] Rodbard, D.: Improved methods for calculating a "figure of merit" for blood glucose monitoring data. Diabetes Technology Meeting, San Francisco, 2005.

[15] Wojcicki, J.: "J"-index. A new proposition of the assessment of current glucose control in diabetic patients. Horm. Metab. Res., $1995,27(1), 41-42$.

[16] Kim, M. I.: An integrated graphic scheme for the display of insulin prescription and blood glucose information. Diabetes Technol. Therap., 2006, 8(4), 505-512.

[17] Hsu, W., Laffel, L., Meneghini, L., et al.: An electronic logbook maintains improvement in glycemic control: observational assessment following a randomized controlled trial. Diabetes, 2006, 55(Suppl. 2), Abstract 396-P.

[18] Jaana, M., Paré, G.: Home telemonitoring of patients with diabetes: a systematic assessment of observed effects. J. Eval. Clin. Pract., 2007, 13(2), 242-253.

[19] Ramachandra, G. N., Samuel, L. E.: Self-monitoring of blood glucose in insulin-requiring type 2 diabetes. Diabetes Technol. Ther., 2008, 10(Suppl. 1), S67-S71.

[20] Russell-Minda, E., Jutai, J., Speechley, M., et al.: Health technologies for monitoring and managing diabetes: a systematic review. J. Diabetes Sci. Technol., 2009, 3(6), 1460-1471.

(Dió Mihály, Budapest, Vas utca 17., 1088 e-mail: diom@se-etk.hu) 